Milka Grbić1

Stevan Luković ${ }^{2}$
JEL: G21, C51, 04

DOI: $10.5937 /$ industrija48-27225

UDC: 005.311:336.717.061(497.11)"2003/2019" 330.35(497.11)

Original Scientific Paper

\title{
The Relationship Between Banks' Credit Activity and Economic Growth: An Empirical Research for the Republic of Serbia
}

\author{
Article history: \\ Received: 23 June 2020 \\ Sent for revision: 28 august 2020 \\ Received in revised form: 5 September 2020 \\ Accepted: 7 september 2020 \\ Available online: 19 October 2020
}

\begin{abstract}
The subject matter of the research study conducted in this paper is the interactive relationship between banks' credit activity and economic growth. In connection with that, the paper is aimed at examining the existence and direction of the cause and effect relationship between the credit activity of the banking sector and the overall economic activity in the Republic of Serbia. The quarterly data related to the period from 2003 to 2019 were collected for the purposes of the research. The share of the loans granted to enterprises in the GDP and the share of the loans granted to households in the GDP are used as the indicators of the credit activity in the study, whereas the real GDP growth rate is determined as the indicator of economic growth. Given the fact that the observed time series are of the different order of integration, the analysis is conducted within the VAR model by applying the Toda-Yamamoto procedure of the Granger causality test. The results of the research show a significant unidirectional causal relationship according to Granger, which starts from the direction of banks' credit activity towards economic growth. The results of the conducted research study can be useful to the makers of the economic policy and the creators of a strategy for the development of the national economy.
\end{abstract}

\footnotetext{
${ }^{1}$ University of Kragujevac, Faculty of Economics, mgrbic@kg.ac.rs

2 University of Kragujevac, Faculty of Economics, slukovic@kg.ac.rs
} 
Keywords: banks' credit activity, economic growth, VAR model, causality according to Granger, Republic of Serbia.

\title{
Odnos između kreditne aktivnosti banaka i ekonomskog rasta: empirijsko istraživanje za Republiku Srbiju
}

\begin{abstract}
Apstrakt: Predmet istraživanja u ovom radu je interaktivni odnos kreditne aktivnosti banaka i ekonomskog rasta. S tim u vezi, cilj rada je da ispita postojanje $i$ smer uzročno-posledične veze između kreditne aktivnosti bankarskog sektora i ukupne ekonomske aktivnosti u Republici Srbiji. Za potrebe istraživanja prikupljeni su kvartalni podaci u periodu 2003-2019. Kao indikatori kreditne aktivnosti, u studiji se koriste udeo kredita odobrenih preduzećima u GDP i udeo kredita odobrenih domaćinstvima u GDP, dok je stopa rasta realnog GDP opredeljena kao pokazatelj ekonomskog rasta. Budući da su posmatrane vremenske serije različitog reda integracije, analiza se sprovodi u okviru VAR modela, primenom Toda-Yamamoto procedure Grejndžerovog testa uzročnosti. Rezultati istraživanja pokazuju da postoji značajna jednosmerna uzročna veza u smislu Grejndžera koja ide iz pravca kreditne aktivnosti banaka ka ekonomskom rastu. Rezultati sprovedenog istraživanja mogu biti korisni kreatorima ekonomske politike i strategije razvoja nacionalne privrede.
\end{abstract}

Ključne reči: kreditna aktivnost banaka, ekonomski rast, VAR model, uzročnost u smislu Grejndžera, Republika Srbija

\section{Introduction}

For centuries now, the basic services rendered by commercial banks have included receiving deposits from clients and approving loans to businesses and households. In addition to the basic jobs, the largest number of banks perform payment turnover services, issuing guarantees, exchange office jobs, the jobs related to foreign trade transactions and many other jobs. Regardless of the number and quality of the services provided, the common characteristic of all traditional commercial banks implies that their deposits are the basic funding resources and approved loans are the most important item of their assets.

The banking sector of the Republic of Serbia is the dominant form of financial intermediation and the most important source of the satisfaction of demand for financial resources. In addition, the financial sector, especially so the banking sector, is one of the most successfully reformed parts of the Serbian economy. Namely, one decade after the beginning of the reformation of the Serbian 38

Industrija, Vol.48, No.2, 2020 
economic sector of the Republic of Serbia, the banking sector received a meaningful role in the financial system at the beginning of the 21 st century. The ownership transformation of banks was carried out, the range of banking products and services was expanded, a more modern, technically equipped manner of operation was established, accompanied by a simultaneous increase in the efficiency of business doing. The strengthening of the deposit potential has enabled a credit expansion, especially in the field of lending to the household sector. Hence, the growing credit activity of banks in the Republic of Serbia over the past two decades has opened up room for questioning whether economic growth is the cause or the consequence of the development of the banking sector. In this regard, this research study is aimed at examining the existence and direction of the cause-and-effect relationship between the credit activity of the banking sector and economic growth on the example of the Republic of Serbia.

The empirical analyses in the above-mentioned context have been conducted on the examples of numerous countries (either individually or as a group), by including different research periods and using different methods and techniques. Due to a pronounced variety originating from different foundations, the different results of the conducted studies regarding the examined causality have been generated. Generally observed, the literature does not provide a consensus on whether the credit activity is the driver of economic growth or the expansion of the real sector causes the intensification of the credit activity or, yet, it is about bidirectional causality.

The evidence of the causality between banks' credit activity and economic growth, primarily in the case of transition countries, can help the makers of the economic policy to determine priority areas in the reform process (Levin, 1998) and the further development of the banking sector. Also, the results of the causal relationship study provide the makers of the economic policy with the useful information necessary to (re)define economic growth and development strategies (Calderón \& Liu, 2003).

Beside the Introduction and the Conclusion, the paper is structured into three more parts. In the first part of the paper, a literature review relevant for the research problem area is given. The second part of the paper deals with the research methodology. In the third part, the obtained results of the empirical research and a discussion of the results are presented. 


\section{Literature Review}

In recent years, the credit activity of banks and its causal relationships with economic growth have been the focus of numerous research studies. King and Levine (1993a; 1993b) were among the first to analyze the correlation between the size indicators and the financial intermediation activities of banks and the rate of economic growth. Their main conclusion implied the existence of a positive, statistically significant partial correlation between the number of the indicators of the development of the banking sector and the annual growth rate of the real GDP per capita. Credit growth was found to have had a significant impact on economic growth in a total of 31 emerging market economies (Garcia-Escribano \& Han, 2015). The unidirectional causal relationship starting from the private sector's credits towards economic growth in Visegrad countries (Gural \& Lomachynska, 2017), Macedonia (Kabashi \& Suleva, 2016), Romania (Duican \& Pop, 2015), Ireland (Kelly et al., 2013), Kenya (lqbal et al., 2012) and Lithuania (Ramanauskas, 2005) was also empirically confirmed. On the other hand, numerous empirical research studies have determined unidirectional causality from the direction of economic growth towards the credits approved by commercial banks. In connection with that, the leading influence of economic growth on banks' credit activity was established in Palestine (Awad \& Al Karaki, 2019), Russia (Ono, 2017), Pakistan (Mushtaq, 2016) and China (Liang \& Teng, 2006), whereas the bidirectional causal relationship was detected in Poland (Škare et al., 2019).

By applying the generalized method of moments to panel data, Zeqiraj et al. (2020) determined the positive and significant influence of the banking sector performance on economic growth in a total of 13 Southeastern European countries in the period from 2000 to 2015 . The hypothesis implying the existence of a positive relationship between the loans granted to the private sector and economic growth, although the relationship disappeared during the hyperinflationary period, was confirmed by Cojocaru et al. (2011) on a sample of the former socialist countries of Central and East Europe and the Community of Independent States. This confirmed the fact pointed out by Rousseau and Wachtel (2002), according to whom the effect of lending is positive and significant only if inflation is below $5-6 \%$. When the inflation rate exceeds $15-$ $25 \%$, financial deepening no longer leads to economic growth.

Examining the connectedness between economic growth and domestic bank loans on a sample of 58 developed countries and developing countries during the period from 1970 to 2010 , Gozgor (2015) found the statistically significant unidirectional causality that goes from domestic bank loans towards economic growth in seven developing countries. On the other hand, the author found that 40

Industrija, Vol.48, No.2, 2020 
the presence of unidirectional causality from economic growth towards domestic bank loans in five developed economies and in 10 developing economies. On the example of the Baltic states, Lakštutienè and Barkauskaitè (2016) found that there was a moderate positive linear relationship between the credit activity and economic growth, where stronger dependence was present between household loans and the GDP than between loans to nonfinancial corporations and the GDP. Also, the Granger causality test showed that, in Latvia, it was possible to use data from the GDP to forecast the extent of loans to households and nonfinancial corporations. Exploring the relationship between bank loans and the macroeconomic variables such as inflation and economic growth for the 10 selected European countries in the period from 2006 to 2012, Korkmaz (2015) analyzed panel data and found that domestic loans had no impact on inflation, but they did have an impact on economic growth. On the example of Tunisia, it was proven that the domestic loans granted to the private sector had a positive effect on economic growth in the long run, only mentioning the fact that financial instability could jeopardize economic growth in the short run (Jedidia et al., 2014).

By applying the generalized method of moments to panel data on a sample of 16 transition countries from Centran and Southeast Europe, the negative connectedness between the loans approved in favor of the private sector and economic growth was found (Petkovski \& Kjosevski, 2014). Also, the negative impact of bank loans on economic growth was demonstrated in the 14 countries of Central, East and Southeast Europe during the period between 1995 and 2015 (Iwanicz-Drozdowska et al., 2019). The negative influence of bank loans to economic growth was also found on the example of the countries of the European Union (EU-27) for the period from 1990 to 2010 (Leitão, 2012). The analysis carried out on a sample of 25 transition countries conducted by Koivu (2002) showed that the growth of the amount of the bank loans granted to the private sector did not accelerate economic growth. Numerous bank crisis and weak budgetary limitations in the majority of the transition countries were mentioned as the main reasons for such an outcome. Because of these specifics, credit growth has not always been sustainable and, in some cases, has contributed to a decline in the rate of economic growth. The fact that the development of the financial intermediation of banks could not be brought into connection with economic growth was also confirmed on the example of the selected Southeast European countries (Mehl et al., 2005).

For the reason of the foregoing, it can be noted that it is not possible to unilaterally determine the nature and direction of cause and effect relationships between the credit activity of commercial banks and economic growth. Eggoh and Villieu (2014) point to the fact that the outcome of an analysis is influenced 
by a larger number of factors, such as the selected countries, the time period under consideration and the indicators used in the analysis. It is also necessary to take into account the fact that each country implements its own specific economic policy, the results of the taken measures simultaneously depending upon the efficiency of the institutions implementing them (Demetriades \& Hussein, 1996).

Taking into consideration the previously conducted studies, as well as the goal of this study, the following research hypotheses were formulated:

$\mathrm{H} 1$ : The credit activity of banks causes economic growth, ceteris paribus.

$\mathrm{H} 2$ : Economic growth causes the credit activity of banks, ceteris paribus.

H3: There is a bidirectional causal relationship between the credit activity of banks and economic growth, ceteris paribus.

$\mathrm{H} 4$ : The credit activity of banks and economic growth are not causally related, ceteris paribus.

\section{Data and Research Methodology}

The credit activity of banks observed as variations in the extent of loans (Lakštutienè \& Barkauskaitè, 2016) can be traced by using several indicators. In the selection of adequate indicators, among other things, the assumption that the loans approved to the private sector by commercial banks contribute to increased investment and productivity to a much greater extent than the loans approved to the public sector can be the starting point. Loans to the private sector are also considered to be approved under stricter conditions and the improvement of the quality of investment is considered to be derived from an assessment of financial intermediaries' justification for a project (Levine \& Zervos, 1998; Levine, 1998). Bearing in mind a research study by Beck et al. (2008), separate indicators were included in the analysis in this paper: the share of the bank loans approved to private enterprises in the nominal GDP and the share of the bank loans approved to households in the nominal GDP. The nominal values of these indicators were reduced to the real by using consumer price indices.

In empirical analyses, it is common to use the growth rate of the real GDP per capita as the indicator of economic growth. However, since there is no available statistical record of this indicator at the quarterly level, the growth rate of the real GDP was used as an alternative indicator (the previous quarter $=100$ ). 
The analysis in this paper includes the time series data for the aforementioned indicators which, in the case of the Republic of Serbia, are available for the period from the first quarter of 2003 all through to the fourth quarter of 2019. The data on the monetary variables were taken from the Database of the National Bank of Serbia (National Bank of Serbia, 2020), while the data pertaining to the nominal GDP and the real GDP growth rates were taken from the database of the Statistical Office of the Republic of Serbia (Statistical Office of the Republic of Serbia, 2020). The analysis of the data was performed by means of the EViews 9 econometric software. An overview and a short description of the variables used in the estimations are given in Table 1 below.

Table 1. The variables considered in the analysis

\begin{tabular}{|l|l|}
\hline \multicolumn{1}{|c|}{ Variable } & \multicolumn{1}{c|}{ Description } \\
\hline ECON $_{\mathrm{t}}$ & The real GDP growth rate \\
\hline CREDE $_{\mathrm{t}}$ & The bank credit approved to a private enterprises (\%GDP) \\
\hline $\mathrm{CREDH}_{\mathrm{t}}$ & The bank credit approved to a household (\%GDP) \\
\hline $\mathrm{t}=$ the period from 2003Q1 to 2019Q4 \\
\hline
\end{tabular}

Source: Authors

Vector Autoregression (VAR) was used to model the linear interdependence between the credit activity of commercial banks and economic growth. The VAR model is a convenient framework which can be presented by appropriate equations relating to the dependency of each variable of its own and the lags of other variables (Jovičić \& Dragutinović Mitrović, 2011). More precisely, the VAR model in our case is the basis for testing the cause-and-effect relationship between the credit activity of the banking sector and economic growth.

In econometrics, the causality concept is interpreted in the Granger sense. According to Granger (1969), X causes $Y(X \rightarrow Y)$ if the values of the variable $Y$ in a future period can be predicted based upon the known values of the variable $\mathrm{X}$ in a previous period, ceteris paribus. In this regard, causality in the Granger sense means that the variable $\mathrm{X}$ is the leading indicator for the variable $\mathrm{Y}$.

The Granger test of the cause of the two stationary variables $y_{t}$ and $x_{t}$ involves the evaluation of the VAR model in the following form:

$$
\begin{aligned}
& Y_{t}=a_{0}+a_{1} Y_{t-1} \ldots .+a_{p} Y_{t-p}+b_{1} X_{t-1} \ldots .+b_{p} X_{t-p}+e_{t} \\
& X_{t}=c_{0}+c_{1} X_{t-1} \ldots .+c_{p} X_{t-p}+d_{1} Y_{t-1} \ldots .+d_{p} Y_{t-p}+e_{t}
\end{aligned}
$$


In empirical analysis, it is often the case that a group of macroeconomic variables are characterized by a mixed order of integration. Hence, the analysis in this paper is conducted by means of a modified technique of the conventional Granger causality test. Specifically, the examination of the causation between the credit activity of banks and the economic growth rate was conducted by the implementation of the Toda-Yamamoto procedures of the Granger causality test (Toda \& Yamamoto, 1995). Unlike the conventional Granger causality test, the Toda-Yamamoto causality test method implies the estimation of the VAR model extended by additional lags, whose number is determined by the maximum order of the integration of the time series whose causality is tested.

To determine the existence of the causal link between the time series, the analysis began with the examination of the nature of the time series in terms of their (non)stationarity. To test the stationarity of the time series of the considered variables, the Augmented Dickey-Fuller (ADF) unit root test (Dickey \& Fuller, 1981) was used. More specifically, the autoregressive equation of the following form was evaluated:

$\Delta X_{t}=\delta_{0}+\delta_{1} t+\delta_{2} X_{t-1}+\sum_{i=1}^{m} \alpha_{i} \Delta X_{t-i}+\varepsilon_{t}$

where: $X_{t}$ is the variable of interest $\left(\mathrm{ECON}_{\mathrm{t}}, \mathrm{CREDE}_{\mathrm{t}}, \mathrm{CREDH}_{\mathrm{t}}\right) ; t$ is the time trend; $\varepsilon_{t}$ is the model error with white noise qualities; $\delta_{0}, \delta_{1}, \delta_{2}, \alpha_{i}$ are a set of the parameters to be evaluated. Based on Equation (2), the zero hypothesis that says a time series has a unit root was tested. $\mathrm{H}_{0}: \delta_{2}=0$, as opposed to the alternative, saying that a time series does not have a unit root, i.e. $H_{1}: \delta_{2}<0$. The alternative hypothesis, according to which a time series is stationary, is accepted for the sufficiently low value of the test statistics, i.e. the negative value that is high enough in the absolute height. The test was done by MacKinnon (1996) test statistics at the 1\%,5\% and 10\% significance levels.

After the examination and determination of the order of integration, it is necessary to estimate the VAR model with the aim of selecting the optimal number of lags that will be applied in the model. It is then necessary to specify the expanded VAR model of the order $p+d_{\max }$ in levels, which in a general case it can be recorded as follows for the two variables:

$Y_{t}=a_{0}+\sum_{i=1}^{p} a_{1 i} Y_{t-i}+\sum_{i=p+1}^{p+d_{\max }} a_{2 i} Y_{t-i}+\sum_{i=1}^{p} b_{1 i} X_{t-i}+\sum_{i=p+1}^{p+d_{\max }} b_{2 i} X_{t-i}+e_{Y_{t}}$ 
$X_{t}=c_{0}+\sum_{i=1}^{p} c_{1 i} X_{t-i}+\sum_{i=p+1}^{p+d_{\max }} c_{2 i} X_{t-i}+\sum_{i=1}^{p} d_{1 i} Y_{t-i}+\sum_{i=p+1}^{p+d_{\max }} d_{2 i} Y_{t-i}+e_{X_{t}}$

(3b)

where $Y_{t}$ and $X_{t}$ are the variables; $a, b, c$ and $d$ are the coefficients; $e_{Y t}$ and $e_{X t}$ are the error terms; $p$ is the optimal lag length, and $d_{\max }$ is the highest order of the integration of the variables.

The Wald test, also known as the Modified Wald (MWald), was then applied to test the significance of the $\operatorname{VAR}\left(p+d_{\max }\right)$ parameters. Namely, based upon Equation (3a), the null hypothesis "(in the Granger sense) $X_{t}$ does not cause $Y_{t}$ ", i.e. $H_{0}: b_{1 i}=0$, was tested against the alternative hypothesis "(in the Granger sense) $X_{t}$ causes $Y_{t}$ ", i.e. $H_{1}: b_{1 i} \neq 0,(i=1 \ldots p)$. Identically, the null hypothesis "(in the Granger sense) $Y_{t}$ does not cause $X_{t}$ ", i.e. $H_{0}: d_{1 i}=0$, was tested from Equation (3b) against the alternative hypothesis "(in the Granger sense) $Y_{t}$ causes $X_{t}$ ", i.e. $H_{1}: d_{1 i} \neq 0,(i=1 \ldots p)$. The MWald test was applied to the first $p$ coefficients of the matrix of the model. The coefficients of the last $d_{\max }$ parameters of the matrix of the model are considered to be equal to zero. In that case, the statistics of the MWald test asymptotically follow the $\lambda^{2}$ distribution. As such, the Wald test statistics are valid, no matter which variables are in question: I(0), I(1) or I(2), on condition that the order of the integration of the variables does not exceed the determined number of lags in a given model (Toda \& Yamamoto, 1995). While testing the Granger causality, the efficiency of the MWald test increases if Seemingly Unrelated Regression Equations (SURE) are used to rate the model (Rambaldi \& Doran, 1996).

\section{Results and Discussion}

To remove seasonal impacts on variables, the time series de-seasoning procedure was conducted by using the X-12 ARIMA methods. The values of the time series were then transformed into a logarithmic shape, except for the ECON time series that had negative values in its structure. In the next step, the presence of the unit root in the observed time series was tested, which was done on a model basis, with the constant and the trend included, and the model, when only the constant was included. The results of the ADF test of the unit root presented in Table 2 indicate the fact that the ECON time series is stationary in the levels. The remaining two time series have the unit root in levels when the constant and the trend are included, and when only the constant is included. By testing the stationarity of the first differences, it was 
concluded that the CREDE and CREDH time series were integrated in the order one, i.e. I(1), or non-stationery in levels, and stationary in the first differences.

Table 2. The results of the ADF Unit Root Test

\begin{tabular}{|c|c|c|}
\hline \multicolumn{3}{|c|}{ In the levels } \\
\hline Variables & Constant, With trend (k) & Constant, No trend (k) \\
\hline ECON & $-4.908854^{*}(1)$ & $-2.663920^{* *}(1)$ \\
\hline $\log C R E D E$ & $-1.381069(1)$ & $-1.847472(2)$ \\
\hline $\log \mathrm{CREDH}$ & $0.103888(1)$ & $-2.169042(1)$ \\
\hline \multicolumn{3}{|c|}{ In the $1^{\text {st }}$ Differences } \\
\hline Variables & Constant, With trend (k) & Constant, No trend (k) \\
\hline$\triangle \log C R E D E$ & $-5.044437^{\star \star}(0)$ & $-4.945348^{* * *}(0)$ \\
\hline$\triangle \log C R E D H$ & $-4.512028^{*}(1)$ & $-4.442922^{* \star}(1)$ \\
\hline \multicolumn{3}{|c|}{$\begin{array}{l}\text { Note: the number of the lags in the model was determined by the Schwarz information } \\
\text { criterion. } \\
\left.\text { The asterisks }\left(^{*}\right),{ }^{* *}\right),\left({ }^{* \star *}\right) \text { denote the statistically significant values at the } 1 \%, 5 \% \text { and } 10 \% \\
\text { significance levels, respectively. }\end{array}$} \\
\hline
\end{tabular}

Source: Own calculations, 2020

The following is the VAR model specification. To do so, it is necessary to determine the optimal number of lags $(p)$. It is important to determine the number of lags in the VAR model for the reason of the validity of the conducted analysis. Should the number of lags be larger than the optimal number be included in the model, then the strength of the test applied is weakened since an additional number of parameters is estimated, simultaneously losing a certain number of freedom degrees. The results of the lag number selection tests are presented in Table 3. As can be seen, the test results are not of a uniform nature. After testing the autocorrelation of the residuals in the VAR models with a different number of lags, a conclusion was drawn that the optimal number of the lags should be 2 .

Table 3. The determination of the number of lags in the VAR model

\begin{tabular}{|c|c|c|c|c|c|}
\hline Lag & LR & FPE & AIC & SC & HQ \\
\hline 0 & NA & 3956.254 & 16.79634 & 16.94474 & 16.81680 \\
\hline 1 & $73.35734^{*}$ & 58.29527 & 12.55653 & $13.15011^{*}$ & 12.63838 \\
\hline 2 & 12.39942 & $57.12758^{*}$ & $12.42931^{*}$ & 13.46808 & $12.57254^{*}$ \\
\hline \multicolumn{6}{|c|}{$\begin{array}{l}\text { Notes: * indicates the lag order selected by the criterion; LR: the sequential modified LR tes } \\
\text { statistics; FPE: the Final Prediction Error; AIC: Akaike Information Criterion, SC: Schwarz } \\
\text { information criterion; HQ: Hannan-Quinn information criterion (each test at a } 5 \% \text { significance } \\
\text { level). }\end{array}$} \\
\hline
\end{tabular}


Furthermore, the stability of the VAR model was tested for the selected number of lags, i.e. for two lags. As can be seen in Figure 1, the absolute values of all the unit roots are within the unit circle, which means that the estimated VAR model is dynamically stable, i.e. stationary.

Figure 1. The Stationarity Test of VAR (3)

Inverse Roots of AR Characteristic Polynomial

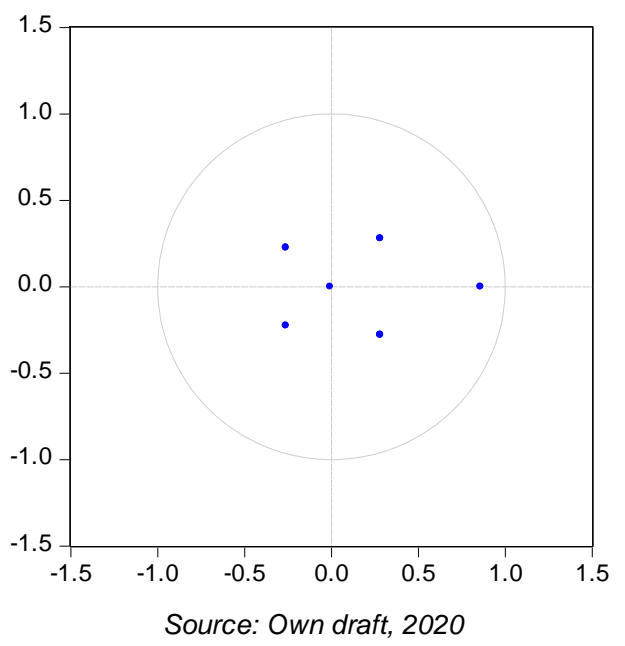

Given the fact that two of the three variables are stationary in the first differences, this means that $d_{\max }=1$, while $p=2$. Therefore, in order to test the causality of the credit activity of banks and economic growth, the specification of the VAR model that consists of three variables in the levels, of the order $k+d_{\max }=2+1=3$ follows. Using the SURE framework, VAR(3) was evaluated as follows:

$$
\begin{aligned}
& {\left[\begin{array}{c}
E C O N_{t} \\
C R E D E_{t} \\
C R E D H_{t}
\end{array}\right]=A_{0}+A_{1}\left[\begin{array}{c}
E C O N_{t-1} \\
C R E D E_{t-1} \\
C R E D H_{t-1}
\end{array}\right]+A_{2}\left[\begin{array}{c}
E C O N_{t-2} \\
C R E D E_{t-2} \\
C R E D H_{t-2}
\end{array}\right]+} \\
& A_{3}\left[\begin{array}{c}
E C O N_{t-3} \\
C R E D E_{t-3} \\
C R E D H_{t-3}
\end{array}\right]+\left[\begin{array}{c}
e_{E C O N} \\
e_{C R E D E} \\
e_{C R E D H}
\end{array}\right]
\end{aligned}
$$


Then, in order to detect the causal relationship of the observed variables, the limitations were tested against the parameters of the models defined in the form of the following hypotheses:

I $\mathrm{H}_{0}: \mathrm{a}_{12^{(1)}}=\mathrm{a}_{12}{ }^{(2)}=0 \rightarrow$ CREDE does not Granger-cause ECON;

II $\mathrm{H}_{0}: \mathrm{a}_{21}{ }^{(1)}=\mathrm{a}_{21}{ }^{(2)}=0 \rightarrow$ ECON does not Granger-cause CREDE;

III $\mathrm{H}_{0}: \mathrm{a}_{13}{ }^{(1)}=\mathrm{a}_{13}{ }^{(2)}=0 \rightarrow$ CREDH does not Granger-cause ECON;

IV $\mathrm{H}_{0}: \mathrm{a}_{31}{ }^{(1)}=\mathrm{a}_{31}{ }^{(2)}=0 \rightarrow$ ECON does not Granger-cause CREDH;

Table 4. Granger Causality Test Results (Toda-Yamamoto procedure)

\begin{tabular}{|l|l|l|l|}
\hline Null Hypothesis & k+dmax & MWald Statistics & p-values \\
\hline $\begin{array}{l}\text { CREDE does not Granger cause ECON } \\
\text { ECON does not Granger cause CREDE }\end{array}$ & $2+1=3$ & $\begin{array}{l}8.183300^{* *} \\
2.820675\end{array}$ & $\begin{array}{l}\mathbf{0 . 0 1 6 7} \\
0.2441\end{array}$ \\
\hline $\begin{array}{l}\text { CREDH does not Granger cause ECON } \\
\text { ECON does not Granger cause CREDH }\end{array}$ & $2+1=3$ & $\begin{array}{l}6.728617^{*} \\
4.563850\end{array}$ & $\begin{array}{l}\mathbf{0 . 0 3 4 6} \\
0.1021\end{array}$ \\
\hline $\begin{array}{l}\text { The asterisks }\left(^{*}\right) \text { and }\left(^{* *}\right) \text { denote the statistically significant values at the } 1 \% \text { and } 5 \% \\
\text { significance levels, respectively. }\end{array}$
\end{tabular}

Source: Own calculation, 2020

Based upon the results presented in Table 4 above, it is concluded that there is a unidirectional causal relationship between the credit activity of the banking sector and the real GDP growth rate in the Republic of Serbia. Namely, the zero hypothesis that CREDE does not Granger-cause ECON is rejected, which means that there is a causal relationship in the Granger sense that goes from the direction of the share of bank loans granted to private companies in the nominal GDP towards economic growth, at a 5\% significance level. Also, the rejection of the zero hypothesis (CREDH does not Granger-cause ECON) confirmed the unidirectional causal link that goes from the direction of the share of bank loans granted to households in the nominal GDP towards economic growth, at a $1 \%$ significance level. On the other hand, the null hypothesis saying that the real GDP growth rate dynamics do not cause the dynamics of the loans granted to enterprises is not rejected, nor is the null hypothesis saying that the real GDP growth rate dynamics do not cause the dynamics of the loans granted to the retail sector rejected, either. More precisely, the obtained results are indicative of the fact that it is not possible to predict the movement of the indicators of the credit activity of the commercial bank sector based upon the movement of the economic growth rate in the observed period. 
All in all, the results of the cause test confirm the validity of the research hypothesis $\mathrm{H} 1$. The findings of this empirical research study are consistent with the results of a number of the works in which the role of the financial sector in the economic growth process is emphasized, which generally proves the fact that the credit activity of commercial banks can be the leading indicator of economic growth (Gural \& Lomachynska, 2017; Černohorský, 2017; Kabashi \& Suleva, 2016; Garcia-Escribano \& Han 2015; Ramanauskas, 2005). At this point, it is important to note that the credit activity of banks is the factor that facilitates economic growth, i.e. the channel that combines savings and investments. In connection with that, the real sources of economic growth lie in the real sector. Technological innovations, the accumulation of both physical and human capital, an increase in the factorial productivity, revealing new natural resources sites, or alternative ways to use the existing resources, are but some of the factors representing the real drivers of economic growth (Grbic, 2016).

\section{Conclusions}

The paper is mainly aimed at examining the existence and nature of the causal relationship between the credit activity of commercial banks and economic growth on the example of the Republic of Serbia. Based on the obtained results, there is a unidirectional causal relationship in the Granger sense, which goes from the credit activity of commercial banks to economic growth. This indicates the fact that the growth rate of the national output can be predicted based upon the variation of the credit activity of the banking sector. Judging by the obtained results, the Serbian banking sector has a vital role in the economic growth process, particularly so when the loans approved to the nonfinancial private sector, i.e. enterprises and households, are concerned.

Bearing in mind the dominant role of commercial banks as financial intermediaries in the financial system of the Serbian economy, further efforts are needed in the maintenance of financial stability and the creation of an ambience where savings will be transferred to the most productive investments. It is recommended that policymakers should put a special emphasis on defining and the implementation of the measures that will result in the deepening of the loan market, especially in light of the institutional and legal measures that protect the rights of both lenders and borrowers and encourage the performance of a contract. In compliance with said, the stimulation of the further development of the financial sector opens up the possibilities of a faster economic growth. 
This paper has certain limitations, primarily in relation to the collected data. The first limitation pertains to the fact that a relatively short time period was analyzed from the point of view of long-term anticipation. Due to the inability to collect long enough data series annually, the available data on a quarterly basis were included in the analysis. The second limitation pertains to the observed time period, especially the second half of the said period, which is marked by the fluctuations that emerged as a consequence of the global recession that appeared at the end of the first decade of the $21^{\text {st }}$ century. In such conditions, the cyclical movement of certain variables may include statistically significant deviations in relation to their long-term tendency.

Since the analysis was conducted with certain limitations, the results of this paper should certainly not be taken as final. Future research could focus on the analysis of the loan structure of the banking portfolio. In this sense, the loans approved to enterprises should be decomposed into investment loans and working capital loans, whereas the loans approved to households should be decomposed into residential and consumer loans, after which connections between individual loan categories and economic growth rates should be tested. A research study within the framework of which a comparative analysis of the connectedness of the credit activity of the banking sector and economic growth in the Republic of Serbia and a selected group of transition countries or a group of upper-middle-income countries would be conducted could also be carried out.

\section{References}

Awad, I.M., \& Al Karaki, M.S. (2019). The impact of bank lending on Palestine economic growth: an econometric analysis of time series data. Financial Innovation, 5:14, 221. doi:10.1186/s40854-019-0130-8

Beck, T., Büyükkarabacak, B., Rioja, F., \& Valev, N. (2008). Who gets the credit ? and does it matter ? household vs. firm lending across countries. Policy Research Working Paper Series 4661, Washington, D.C.: World Bank. Retrieved from http://documents1.worldbank.org/curated/en/380681468138868905/pdf/WPS466 1.pdf

Calderón, C., \& Liu, L. (2003). The Direction of Causality between Financial Development and Economic Growth. Working Paper No 184, Central Bank of Chile. Retrieved from https://si2.bcentral.cl/public/pdf/documentos-trabajo/pdf/ dtbc184.pdf

Cojocaru, L., Hoffman, S., \& Miller, J. (2011). Financial Development and Economic Growth in Transition Economies: Empirical Evidence from the CEE and CIS Countries. Working Paper No 2011-22, Department of Economics, University of 
Delaware. Retrieved from https://lerner.udel.edu/sites/default/files/ECON/ PDFs/ RePEc/dlw/WorkingPapers/2011/UDWP2011-22.pdf

Černohorský, J. (2017). Types of bank loans and their impact on economic development: a case study of the Czech Republic. E\&M Ekonomie a Management, 20(4), 34-48. doi:10.15240/ tul/001/2017-4-003.

Demetriades, P. O., \& Hussein, K. A. (1996). Does Financial Development Cause Economic Growth? Time Series Evidence from 16 Countries. Journal of Development Economics, 51(2), 387-411. doi:10.1016/S0304-3878(96)00421-X

Dickey, D. A., \& Fuller, W. A. (1981). Likelihood ratio statistics for autoregressive time series with a unit root. Econometrica, 49(4), 1057-1072. doi:10.2307/1912517

Duican, E, R, \& Pop, A. (2015). The implications of credit activity on economic growth in Romania. Procedia Economics and Finance, 30, 195 - 201. doi:10.1016/S22125671(15)01286-1

Eggoh, J.C., \& Villieu, P. (2014). A simple endogenous growth model of financial intermediation with multiplicity and indeterminacy. Economic Modelling, 38, 357366. doi:10.1016/j.econmod.2014.01.017

Garcia-Escribano, M., \& Han, F. (2015). Credit Expansion in Emerging Markets: Propeller of Growth?. IMF Working Paper 15/2012. Retrieved from https://www.imf.org/external/pubs/ft/wp/2015/wp15212.pdf

Gozgor, G. (2015). Causal relation between economic growth and domestic credit in the economic globalization: Evidence from the Hatemi-J's test. The Journal of International Trade \& Economic Development, 24(3), 395-408, doi: 10.1080/09638199.2014.908325

Granger, C. W. J. (1969). Investigating Causal Relations by Econometric Models and Cross-spectral Methods. Econometrica, 37(3), 424-438. doi:10.2307/1912791

Grbic, M. (2016). Interaction between financial intermediation efficiency and economic growth. Economic Horizons, 18(3), 241-254. doi:10.5937/ekonhor1603247G

Gural, A., \& Lomachynska, I. (2017). FDI and financial development as determinants of economic growth for v4 countries. Baltic Journal of Economic Studies. 3(4), 5964. doi:10.30525/2256-0742/2017-3-4-59-64

Iqbal, M.Z., Ahmad, N., \& Hussain, Z. (2012). Impact of Savings and Credit on Economic Growth in Pakistan. Pakistan Journal of Social Sciences (PJSS), 32(1), 39- 48. Retrieved from https://pdfs.semanticscholar.org/34ad/ccd1e3ad726cebd 69e45c 41892257d843ad3.pdf

Iwanicz-Drozdowska, M., Bongini, P., Smaga, P., \& Witkowski, B. (2019). The role of banks in CESEE countries: exploring non-standard determinants of economic growth. Post-Communist Economies, 31(3), 349-382. doi: 10.1080/14631377. 2018.1505694

Jedidia, K.B., Boujelbene, T., \& Helali, K. (2014). Financial Development and Economic Growth: New Evidence from Tunisia. Journal of Policy Modeling, 36(5), 883-898. doi:10.1016/j.jpolmod.2014.08.002

Jovičić, M., \& Dragutinović Mitrović, R. (2011). Ekonometrijski metodi i modeli. Centar za izdavačku delatnost Ekonomskog fakulteta u Beogradu, Beograd.

Kabashi, R. \& Suleva, K. (2016). Loan Supply Shocks in Macedonia: A Bayesian SVAR Approach with Sign Restrictions. Croatian Economic Survey, 18(1), 5-33. https://doi.org/10.15179/ces.18.1.1

Industrija, Vol.48, No.2, 2020 
Kelly, R., McQuinn, K., \& Stuart, R. (2013). Exploring the Steady-State Relationship between Credit and GDP for a Small Open Economy: the Case of Ireland. ECB Working Paper 1531, Frankfurt: European Central Bank. Retrieved from https://www.ecb.europa.eu/pub/pdf/scpwps/ecbwp1531.pdf

King, R.G. \& Levine, R. (1993a). Finance, Entrepreneurship, and Growth: Theory and Evidence. Journal of Monetary Economics, 32, 513-542. Retrieved from https://www.sciencedirect.com/science/article/abs/pii/030439329390028E

King, R.G., \& Levine, R. (1993b). Finance and Growth: Schumpeter Might Be Right. Quarterly Journal of Economics, 108(3), 717-737. doi:10.2307/2118406

Koivu, T. (2002). Do efficient banking sectors accelerate economic growth in transition economies?. Discussion Paper No 14. Bank of Finland, Institute for Economies in Transition. Retrieved from https://econwpa.ub.uni-muenchen.de/econwp/mac/papers/0212/0212013.pdf

Korkmaz, S. (2015). Impact of Bank Credits on Economic Growth and Inflation. Journal of Applied Finance \& Banking, 5(1), 57-69. Retrieved from http://www.scienpress.com/Upload/JAFB/Vol\%205_1_4.pdf

Lakštutienè A., \& Barkauskaitè A. (2016). Evaluation of relationship between banks lending activities and the economies in Baltic countries. Copernican Journal of Finance \& Accounting, 5(1), 141- 156. http://dx.doi.org/10.12775/CJFA.2016.008

Leitão, N.C. (2012). Bank Credit and Economic Growth: a Dynamic Panel Data Analysis. The Economic Research Guardian, 2(2), 256-267. Retrieved from http://www.ecrg.ro/files/p2012.2(2)17y8.pdf

Levine, R. (1998).The Legal Environment, Banks, and Long-Run Economic Growth. Journal of Money, Credit, and Banking, 30(3), 596-613. DOI: 10.2307/2601259

Levine, R., \& Zervos, S. (1998). Stock Markets, Banks, and Economic Growth. The American Economic Review, 88(3). 537-558. Retrieved from https:// www.jstor.org/stable/116848?seq $=1$

Liang, Q., \& Teng, J.Z. (2006). Financial Developmentandd Economic Growth: Evidence from China. China Economic Review, 17(4), 395-411. doi:10.1016/j.chieco. 2005.09.003

MacKinnon, J.G. (1996). Numerical distribution functions for unit root and cointegration tests. Journal of Applied Econometrics, 11(6), 601-618. doi: 10.1002/(SICI)10991255(199611)11:6<601::AID-JAE417>3.0.CO;2-

Mehl, A., Vespro, C., \& Winkler, A. (2005). The finance-growth nexus and financial sector environment: new evidence from Southeast Europe. Conference on European Economic Integration, Austrian National Bank, Vienna. Retrieved from https://pdfs.semanticscholar.org/e487/0bccda199c69fa2086d0bccd58af4fbc8062 .pdf

Mushtaq, S. (2016). Causality between bank's major activities and economic growth: evidences from Pakistan. Financial Innovation 2:7, 2-11. doi:10.1186/s40854016-0024-y

National Bank of Serbia. (2020). Consolidated Balance Sheet of the Banking System. Belgrade: National Bank of Serbia. Retrieved from https://www.nbs.rs/ internet/ english/80/index.html

Ono, S. (2017). Financial development and economic growth nexus in Russia. Russian Journal of Economics, 3(3), 321-332. doi:10.1016/j.ruje.2017.09.006 
Petkovski, M., \& Kjosevski, J. (2014). Does banking sector development promote economic growth? An empirical analysis for selected countries in Central and South Eastern Europe. Economic Research-Ekonomska Istraživanja, 27(1), 5566, DOI: 10.1080/1331677X.2014.947107

Ramanauskas, T. (2005). Assessment of Bank Credit Growth from Macroeconomic Perspective. Pinigu studijos, 2005/3, 78-97.

Rambaldi, A. N., Doran, H. E. (1996). Testing for Granger Non-Causality in Cointegrated Systems Made Easy. Working Paper in Econometrics and Applied Statistics, 88, University of New England. Retrieved from http://aliciarambaldi.net/doc/wp88.pdf

Rousseau, P.L., Wachtel, P. (2002). Inflation thresholds and the finance-growth nexus. Journal of International Money and Finance, 21, 777-793. Retrieved from http://pages.stern.nyu.edu/ pwachtel/images/RW_JIMF2002.pdf

Statistical Office of the Republic of Serbia. (2020). National accounts. Belgrade: Statistical Office of the Republic of Serbia. Retrieved from https://data.stat.gov.rs/?caller=SDDB\&languageCode=en-US

Škare, M., Sinković, D., \& Porada-Rochoń, M. (2019). Financial Development and Economic Growth in Poland 1990-2018. Technological and Economic Development of Economy, 25(2), 103-133. doi:10.3846/tede.2019.7925

Toda, H. Y., \& Yamamoto, T. (1995). Statistical inferences in vector autoregressions with possibly integrated processes. Journal of Econometrics, 66(1-2), 225-250. doi:10.1016/0304-4076(94)01616-8

Zeqiraj, V., Hammoudeh, S., Iskenderoglu, O., \& Kumar Tiwari, A. (2020). Banking sector performance and economic growth: evidence from Southeast European countries. Post-Communist Economies, 32(2), 267-284, doi: 10.1080/14631377. 2019.1640988 